\title{
On the Translation of Film Titles in Light of Religious Differences between China and West
}

\author{
Huang Suqin ${ }^{1 *}$, Li Xiangyu ${ }^{2}$ \\ ${ }^{1,2}$ Zhejiang Ocean University, Zhoushan, China
}

\author{
*Corresponding Author: Huang Suqin, Zhejiang Ocean University, Zhoushan, China
}

\begin{abstract}
With the mutually cultural exchange of the China and Western countries, more and more English films are introduced to China, and so do the Chinese films to the western countries. Being an important part of a film, the film title plays a critical role in conveying a film's theme and attracting people. Most scholars attach their attention on the methods, cultural differences and principles upon film title translation, while seldom study the influence of religious differences on film title translation. This paper will study the film title translation from the perspective of the religious differences.

Firstly, the author talks about the relationship between religion and language. Then, this paper analyzes the religious differences of the China and the Western countries and points out the effects on film title translation. Thirdly, the author puts forward two resolutions including Eugene Nida's functional equivalence theory to film title translation to achieve aesthetic and commercial values.

The author concludes that due to the existence of the religious differences, translators are supposed to have $s$ good grip and profound knowledge of the religious differences between the China and the Western countries. Only in this way can translators balance the aesthetic and commercial values.
\end{abstract}

Keywords: Religious Differences, Film Title Translation, Functional Equivalence Theory

\section{INTRODUCTION}

The increasing globalization exerts its influence in many different fields like economy, anti-terrorism, technology, especially in cultural exchange. Film is a culture-loaded tool enabling people to spread native culture and absorbing foreign culture in a significant way. The culture and values carried by the western films greatly influence Chinese people's life. The significant role of China in the international arena drives the outside world to eagerly get a better understanding of our country. Films sever a very good way.

The film titles with both aesthetic and commercial values play an important role in attracting people and making excellent box office revenues .Film title translation, however, has not been deeply researched. And the current researches about the film title translation are limited to mainly three types. The first type is to study the principles which should be used in the film title translation. They believe that film title translation should follow four principles--- principle of economic benefit, of informative function, of cultural value and of aesthetic value. The second one focuses on how cultural differences influence the film title translation. The third type is about the methods or skills applied in the translation, namely literal translation, liberal translation or domestication and alienation. And the pros and cons of the literal translation and liberal translation or the domestication and alienation are also studied. Recently, some scholars turn to study how the cultural differences influence the film title translation from the perspective of history, human geography and thinking pattern. But this kind of study as well as the foregoing study groups stops at the very general level and they fail to point out why film title translation sometimes cannot achieve the faithfulness in the language level.

Then the author talks about the relationship between language and religion, and the effects of religious differences between the East and the West upon film title translation. This paper also discusses the general ways to deal with it.

\section{THE RELATIONSHIP BETWEEN LANGUAGE AND RELIGION}

\subsection{Language, the Major Carrier of the Religion}

Language, as the special and vital part of human culture, is regarded as the most important 
communicative tool used to storage and spread feelings, information and culture. Armed with its uniquely powerful information transfer and interpersonal interaction function, language leads to the birth of society and the development of culture. And due to the strong social function, language embodies and symbolizes people's understandings of the objective reality making it possible to transfer and communicate information. Without language people are unable to communicate with others let alone to build a society, or create culture.

Being an indispensable part of human life, language contributes fundamentally to the spread of religious doctrines, spirit and thoughts. Take Buddhism for example, in order to preach the creeds, Buddha Shakyamuni had allowed his pious adherents to use their own dialects to popularize Buddhist teachings. That is to say, without language the Buddhism would not develop and spread widely. Language is a medium to convey religious sentiments, teach doctrines. Language is the basis of the religion.

\subsection{Religion's Promotion to the Development of Language}

Religion exists in human beings' life from primitive stage to the modern time. With the help of language it shapes people's attitudes and values towards the outside world. It builds a nation's literature and art, morality and ethics, institutions and conventions. From the history of linguistics religion and language are deeply and closely bound. Religion promotes the development of language, and enriches vocabulary.

At the very beginning preachers spread spirit to disciples by using Greece and Latin. To have a good understanding of Bible and shorten the distance with God, pious Christians try to command these two languages which in some degree helps the developing process of languages. Many words we use actually originated from religion. The word--- “安心”(ease) refers to set one's heart at rest or not worry about anything which is a Buddhist word. And another Buddhist word “领悟”(comprehend) is originally used to describe someone understand the truth or doctrines of Buddhism, then its usage not only limited to the Buddhist level but widely used to describe the understanding of the essence of everything. The idioms “灵丹妙药” and “八仙过海, 各显神通” coming from the Taoism respectively mean "catholicon" and "When the eight immortals cross the sea, everyone uses their special prowess". Similarly some English words also come from Bible. Book of Genesis says that Eve, wife of Adam, was made from his rib. So people used the word "rib"to refer to wife and then "Eve" replaced "rib". "Minister" meant preacher of churches which is used to refer to the head of state department or Member of Parliament. Religion penetrates into proverbs, proverbial expressions, idioms, adages and literary quotations.

\section{RELIGIOUS DIFFERENCES BETWEEN WESTERN AND CHINESE}

\subsection{Polytheism vs. Monolatrism}

Different from the West, China is a three-teaching country. Confucianism, Buddhism and Taoism are the three major religions owning a large number of followers in China, especially the Buddhism. The Hundred Schools of Thought emerged and flourished in The Spring and Autumn Period and The Warring State, and then Confucianism had dominated the society since the Western Han Dynasty. One of Chinese noticeable cultural features is inclusive. We can see it from Confucius' famous saying that“君子和而不同(Gentlemen seek harmony but not uniformity)"and the well-known sentence from I Ching“天行健, 君子以自强不息; 地势坤, 君子以厚德载物(As heaven maintains vigor through movements, a gentleman should constantly strive for self-protection. As earth's condition is receptive devotion, a gentleman should hold the outer world with broad mind)." That's why other schools of thought didn't fade away from Chinese history. For example, Taoism still existed and became prevalent in Tang Dynasty. Confucianism Buddhism and Taoism can coexist harmoniously and even draw merits to benefit Chinese.

When it comes to why westerners only convert to one religion, Bible gives us a perfect explanation. On the top of Mount Sinai, God made Ten Commandments with Moses prohibiting sons of Israels to worship any other Gods."I am the LORD your God, who brought you out of the land of Egypt, out of the house of slavery. You shall have no other gods before me." [1] This kind of ban is very common in Bible. For example, "yet for us there is one God, the Father, from whom all things and for whom we exist, and one Lord, Jesus Christ, through whom are all things and through whom we exist."'[2] There is no doubt that westerners only have one religion and on Chinese films telling stories of religion, for 
example the movie “八仙过海” has to be translated into “The Eight Fairies" .In Christianity we cannot find any equivalent referents. The translator has to use a very familiar character in Ancient Greek Mythology---fairy.

\subsection{Goodness of Human Nature vs. Theory of Original Sin}

Concerning the eternal question that whether the human nature is good or evil, eastern and western religions give us a widely divergent answer. Mencius proposed “水信无分于东西, 无分于上下乎? 人之性善也, 犹水之就下也。人无有不善, 水无有不下”[3]（There is no eastward or westward flow of water, but it has the up flow and down flow. Like water always flowing downward, human nature is always good.) And Buddhism holds the same views that “心性本净” (luminous mind）and“人性本善”(goodness of human nature).From this point, we can see that Chinese religion has the tendency to believe that human nature is good.

On the contrary, Christianity sees that man is sinful and man is born to atone for his crime."Indeed, I was born guilty; a sinner when my mother conceived me"[4] it shows that in Christianity man is believed to be born with original sin. It was caused by the ancestors of human beings Adam and Eve who were tempted by the serpent to eat forbidden fruit and then driven out of garden of Eden. Since then the human nature is considered immoral and culpable.

\subsection{Man's Unity with Heaven vs. Separation of God and Man}

Located at the fertile and East-Asian zone, China was favored by the nature. Productive soil, pleasant climate, semi-closed geographical conditions determined Chinese traditional economic mode---natural agricultural economy. The natural agricultural economy shaped Chinese outlook of being with nature. Confucianism and Taoism attach great attention to the relationship with nature. It seems that Heaven is only the symbol of nature. But in Chinese Heaven refers to God, the ruler of human beings.

Living on the prairie by the Euphrates River, ancestors of Hebrews made a living upon nomadism, especially tended sheep. There are a lot of stories of shepherd and sheep. In the Bible shepherd is God and sheep are the symbol of chosen people or pious adherents of God. For example "He will feed his flock like a shepherd: he will gather the lambs in his arm, and carry them in his bosom, and gently lead the mother sheep"[5] and "Your servant used to keep his father's sheep, and whenever a lion and a bear came, and took a lamb from the flock. I went after him, and stroke it down, rescuing the lamb from its mouth; and if it turned against me, I would catch it by the jaw, strike it down, and kill it."[6] and "The LORD who saved me from the paw of the lion and from the paw of the bear, will save me from the hand of Philistine"[7]Man resigns to God who is the only ruler of universe. In other words, God is superior to human beings, to all things in earth. God is the embodiment of authority. Distinguished from Christianity, Chinese emphasize the harmony between human and nature, and even has the belief “人定胜天”(Man's will, not Heaven, decides).

In Chinese literature, writers and poets are apt to link their affections with nature. For example $\mathrm{Yu}$ Guangzhong (1928-2017) once wrote a prose of rain to express his homesickness “惊蛰一过, 春寒加剧。先是料料峭峭, 继而雨季开始, 时而淋淋漓漓, 时而淅淅沥沥, 天潮 潮地湿湿, 即连在梦里, 也似乎有把伞撑着。不过那一块土地是久违了, 二十五年, 四分之一的世纪, 即使有雨, 也隔着千山万山, 千伞万伞。十五年, 一切都断了, 只有气候, 只有气象报告还牵连在一起, 大寒流从那块土地上弥天卷来, 这种酷冷吾与古大陆 分担。不能扑进她怀里, 被她的裙边扫一扫也算是安慰孺慕之情吧。”[8] In the famous novel of Jane Austin(1775-18) Pride and Prejudice there is a description of rain "Her hopes were answered; Jane had not been gone long before it rained hard. Her sisters were uneasy for her, but her mother was delighted. The rain continued the whole evening without intermission; Jane certainly could not come back."'[9]In western literature the role of nature is to provide a background rather than indicating protagonists' feelings. It's clear to see that Chinese are closely connected with nature, and for the westerners there is an aloof distance between man and nature. A Chinese film's title “天地英雄”puts Heaven and Earth the represent of Gods and the hero which stands for human at the same level to prove that Chinese adamantine belief---harmony between Man and Heaven.

\subsection{Influences of Religious Differences on Film Title Translation}

Language and religion are closely connected. Language is the carrier of religion conveying a nation's belief, values and worldviews. Without religion the language would not be so rich and colorful. The 
religion of the East and the West differs a lot from each other, it's a hard job to find proper equivalences between two words with religions implication when translating film titles.

Firstly, translators are incapable to get the symbolic meaning. In Bible, God is considered as shepherd and sheep mean chosen people or pious followers of God. But in China there is no similar or same symbols. Thereof it's difficult for Chinese people to understand the real meaning of shepherd and sheep. For example, the film The good shepherd directed by Robert De Niro telling the life stories of Edward Wilson, one of the founders of CIA, was translated into “牧羊人”.The Chines version easily confused audience of China who aren't familiar with Christianity and misled them to think the film was about a herder how to keep sheep. Another Chinese version “特务风云” suits the film much better.

Secondly, translators misunderstand the religious images. Take the film Ocean's Eleven for example, it has many translated Chinese versions. One of the versions is “十一罗汉”. “罗汉”(Buddha) in Buddhism refers to disciple of Buddha who has the ability to eradicate root of all worries and has no desire for anything. Using “罗汉”(Buddha) to refer to the eleven talented robbers is not suitable. Apparently it results from the misunderstanding the religious images.

Thirdly, the same character may have completely different religious meaning. For instance, in western religion dragon stands for evil . "Speak and say, Thus says the LORD GOD;I am against you; Pharaoh of Egypt, the great dragon sprawling in the midst of his channels, saying,, My Nile is my own; I have made it for myself" [10].Furthermore, there is another description in Bible "Awake, awake, put on strength, $\mathrm{O}$ arm of the LORD! Awake, as in days of old, the generations long ago! Was it not you who cut Rahab in pieces, who pierced the dragon? "[11]Contrary to western religion, dragon in China is a propitious omen representing emperors. When translating Chinese films, for example “游龙戏风” “鼠胆龙威”“卧虎藏龙”, attention should be paid to the religious differences.

Despite these religious differences, Christianity and Confucianism Buddhism and Taoism have something in common. The Chinese translation version “七宗罪” of the film Seven Sins is easy for Chinese to understand. There are similar sins in religions of West and East.

Christianity: Seven deadly sins

1) greed 2) lust 3) gluttony 4)envy 5)sloth 6)pride 7)wrath

Buddhism:八戒
1）戒杀生 2）戒偷盗
3)戒淫邪
4)戒妄语
5)戒饮酒
6)戒奢华
7)戒坐卧高广大床
8)戒非时食

\subsection{Methods of Dealing with Faithfulness in the Translation of Film Titles}

Since the differences of the eastern and western religion, finding the lexical and grammatical equivalences is not easy. Translation doesn't mean reaching the level of sameness in lexicality and grammar. So as to achieve the goal of dealing with faithfulness resulted by religious differences in film title translation properly, the translator's excellent grip of two religions is of help to find the suitable religious and cultural replacements. Eugene A. Nida proposed his famous dynamic equivalence. This theory holds the view that translators should use the utmost suitable natural equivalences of target language to accord with source language and convey both literal and cultural meanings. However, when translators fail to convey both literal and cultural meaning, it's allowed to adopt new literal form of the source language to convey the cultural meaning. If the new literal form cannot meet the requirement to express the original cultural meaning of source language, translators should take the method of recreating. Recreation means using words of the target language to convey the cultural meaning of source language.

\section{CONCLuSion}

Film title translation is an important and necessary part of film translation, however, there is few researches about relationship between religious differences and film title translation. This paper targets to get people's attention to the significant influences of religious differences between China and West upon film title translation. Because of the religious differences, translators fail to achieve the 
goal of translating the film titles faithfully. So the paper puts forward Dynamic Equivalence and requests translators to have a good command of two religions.

Language and religion are the two aspects of human culture. They are independent systems but have interaction with each other. Language serves as the major carrier of religion, mirroring the religious doctrines and worldviews. Religion influences language and enriches language. This paper discuss the differences between religions of China and West respectively. Through studying the religious differences completely, we find how the influences of religious differences upon film title translation. To learn the religious differences of Chinese and westerners contributes to translation. In order to find a better film title translation, translators are not only required to grasp two religions but to apply Dynamic Equivalence flexibly.

\section{REFERENCES}

[1],[2],[4],[5],[6],[7],[10],[11]]Holy Bible.Nanjing: National TSPM\&CCC,2000

[3]Yang,Bojun. 《Translation Note of Mencius》.Beijing: Zhonghua Book Company, 2012

[8]Yu,Guangzhong. 《Classic Works of Yu Guangzhong》.Beijing: The Contemporary World Press, 2007

[9] Austen, Jane .Pride and Prejudice .Beijing: China International Press, 2012

\section{AUTHOR'S BIOGRAPHY}

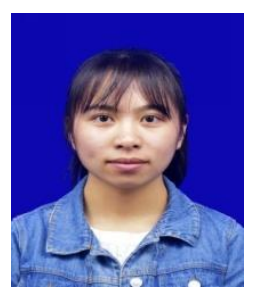

Suqin HUANG, was born on $9^{\text {th }}$ March, 1996.I am junior of Foreign Language College, Zhejiang Ocean University, majoring in English.

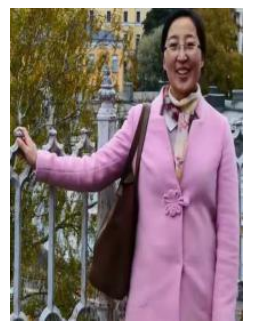

Xiangyu, Li, Lecturer of Foreign Language College, Zhejiang Ocean University, China. Master of Arts in Literature and Language, Beijing Normal University. Research area: European and American literature, the Second Language teaching.

Citation: Huang Suqin, Li Xiangyu. "On the Translation of Film Titles in Light of Religious Differences between China and West" International Journal on Studies in English Language and Literature (IJSELL), vol 6, no. 4, 2018, pp. 26-30. doi:http://dx.doi.org/10.20431/2347-3134.0604003.

Copyright: () 2018 Authors. This is an open-access article distributed under the terms of the Creative Commons Attribution License, which permits unrestricted use, distribution, and reproduction in any medium, provided the original author and source are credited. 